\title{
Louise Michel e a Comuna de Paris (1871)
}

\author{
Samanta Colhado Mendes* \\ samantacolhadomendes@yahoo.com.br
}

Resumo: O presente artigo tem como objetivo essencial compreender a Comuna de Paris de 1871, como uma experiência histórica de luta que obteve fundamental importância para os movimentos operários de períodos subsequentes em todo o mundo. Elaboramos o artigo através da perspectiva de seus sujeitos históricos, resgatando as memórias, trajetórias e ideias presentes nos relatos de Louise Michel, uma das mais ativas personagens da Comuna. Inicialmente uma republicana, quando da guerra franco-prussiana (1870), Louise trouxe dessa experiência as raízes e o conhecimento para a prática do seu anarquismo convicto, na luta que envidaria em defesa da Comuna, até os últimos combates em maio de 1871. Louise Michel, no entanto, não encerrou sua luta libertária ao fim da Comuna de Paris; continuou lutando no exílio, na Nova Caledônia, e em toda Europa após a anistia de 1880.

Palavras-chave: Louise Michel, História Social, Comuna de Paris, movimento anarquista.

No ano de 2011, após 140 anos, relembramos e buscamos resgatar a memória de uma experiência história de fundamental importância para as lutas da classe trabalhadora de fins do século XIX, por todo século XX, e que tem ecos profundos ainda hoje - a Comuna de Paris de 1871. Não são raros os escritos sobre o tema, assim como não o são as discussões sobre ele. Desde as seções da Primeira Internacional dos Trabalhadores (a AIT), debates eram travados sobre as práticas adotadas nos dias da Comuna, sobre os arcabouços teóricos que a sustentavam, assim como sobre sua importância para as ações dos proletários nos períodos que se seguiram a sua queda. Marx e Engels - mesmo ressaltando que os communards (como eram denominados os membros da Comuna) não haviam "esperado", nem observado as condições objetivas necessárias para a revolução - colocavamna como experiência valiosa para as lutas trabalhadoras. Bakunin e outros

\footnotetext{
* Mestre em História Unesp/Franca.
} 
coletivistas, por outro lado, afirmavam-na como organização autogerida pela qual lutavam. Há grande valor em suas obras, em suas argumentações sobre a Comuna, porém, há ainda outros relatos e trajetórias de indivíduos que participaram e lutaram ativamente nos dias de luta pelas ruas de Paris. Estes nos permitem "reconstruir" - utilizando um termo de Paul Thompson (1992) - os acontecimentos, as formas de organização e até a vida cotidiana de homens e mulheres que atuaram ativamente como communards. Resgatar as reminiscências dos indivíduos, atores desse processo histórico, através de suas ideias, relatos e cartas é resgatar a memória da própria Comuna de Paris de 1871.

Certamente, entre esses indivíduos, uma das mais ativas lutadoras foi Louise Michel, que estudaremos ao longo desse texto. Através de sua perspectiva, compreenderemos os acontecimentos que antecederam e culminaram com a proclamação da Comuna, assim como entenderemos a trajetória de intensas lutas desta que se tornou uma grande anarquista. Louise foi e ainda é referenciada entre libertários do mundo inteiro.

Seus diversos escritos - como A Comuna, volume 1 e 2 (publicado originalmente sob o título de La Commune: histoire et souvenirs I et II em 1898 , exatamente oito anos depois da anistia geral concedida aos participantes da Comuna e de seu retorno da prisão da Nova Caledônia); Mis recuerdos de la Comuna (versão espanhola de suas memórias, que conta com manifestos dos internacionalistas participantes da Comuna); e suas Cartas a Victor Hugo (trocadas com aquele que ela considerava seu grande mestre desde a juventude) - trazem narrações, em relatos carregados de pensamentos, impressões, anseios e sentimentos dos acontecimentos dos quais participou intensamente: sua luta pela instauração da República e a consequente desilusão com essa forma de governo, os inúmeros levantes que culminaram com as eleições da Comuna pela população parisiense, e os dois meses em que ela se dedicou à luta armada. Em tais registros, assim como em sua biografia, escrita por Irma Boyer (1946), fica claro e evidente que Louise Michel não tinha a Comuna apenas como forma de resistir à ocupação prussiana, mas como possibilidade de construção de uma sociedade livre e igual para todos, sem distinção. Além disso, essas memórias são a expressão de uma das mais ativas personagens que atuaram nos meses de luta nas ruas de Paris.

Aqui, no entanto, não nos ateremos somente aos dias de luta de Louise Michel entre os communards, mas, sim, em sua própria história de vida e curso político, como um todo, que culminou com sua atuação no $61^{\circ}$ Batalhão de Marcha na Comuna de Paris de 1871. Nesse sentido, destacaremos a sua história sobre essa experiência, a sua forma de enxergá-la, ou seja, os eventos 
e fatos aqui explicitados foram contados por ela em relatos e memórias deixados para a posteridade. Trata-se da História da Comuna contada por Louise Michel, para quem essa forma de organização significava a realização completa dos ideais presentes entre seus participantes.

Marianne Michel, mãe de Louise, trabalhava como empregada doméstica em um castelo na cidade de Vroncourt (França), cujo proprietário era Étienne-Charles Demahis, um ex-magistrado adepto das ideias da Revolução Francesa de 1789, principalmente no que tange aos direitos humanos. Foi nesse castelo que Marianne engravidou, o que provocou inúmeras discussões entre os familiares. Étienne acusava seu filho Laurent de ser o pai da criança, mas o mesmo negava tal versão até o ponto de sair de sua casa. Em 29 de maio de 1830, nascia Louise Michel, que foi criada como filha da família. Em uma de suas cartas escrita ainda na adolescência a Victor Hugo - amigo e mestre com o qual trocava cartas, confidências e (segundo estudiosos) com quem teve um encontro amoroso -, ela lhe contava, com grande angústia, tristeza e dúvida, sobre a possibilidade de ser filha daquele a quem chamava de avô; seu suposto pai não tinha motivos para assumir o filho de uma empregada, considerando ser casado com uma camponesa com quem tinha herdeiros; esses "prováveis" irmãos de Louise a visitavam com certa frequência. "Ainda há, todavia, uma de minhas dores que preciso vos contar. É algo horrível. É de se duvidar da fraqueza de minha mãe. Meu pai sustentava que eu era sua irmã e não filha" (Michel, 2005, p. 34).

Apesar das controvérsias e sem nunca assumir a paternidade, Étienne e sua esposa Louise-Charlotte Mexence Porquet deram a ela uma educação carregada de ideais como liberdade, igualdade e fraternidade, assim como lhe proporcionaram um grande contato com as artes (como a música e a poesia), com a natureza (já que o castelo possuía uma imensa área com árvores frutíferas e pequenas montanhas) e com os animais. Louise afirmava, também em cartas a Victor Hugo, experimentar todos os tipos de sentimentos nesse ambiente, desde a plenitude e a felicidade, até intensas dores.

[...] minha avó educara em sua casa a filha de uma pobre viúva. Seu filho a amou e depois a abandonou, a ela e à criança. Era minha mãe. Todo mundo os rejeitava, mas apesar da criança, os dois anciãos nos estenderam os braços. Passaram-se, então, disseram-nos, cenas terríveis entre os membros da família, e eu era a causa de tudo aquilo, sem nem o saber. Eis por que me desprezavam, Hugo.

Não posso contar-vos todas as impressões de minha infância. É uma mistura de dor, de alegria, de sonhos, de destino e dessa ideia da fatalidade na qual minha mãe acreditava. Lembro-me de que, um dia, uma velha 
senhora me acalentava nos braços dizendo: "Vá dormir no cemitério, pequena”. Essas palavras ficaram para sempre em meu coração como uma maldição. [...]

Agora, tudo isso, me parece um sonho. Ainda ouço minha avó que me consolava, chorava junto comigo, ou cantava para mim longas romanças. Quantas lembranças tenho desse tempo em que eu estava ora muito feliz, ora já cansada da vida. (MicheL, 2005, p. 29 e 30; grifos nossos)

Foi durante a adolescência, nesse castelo, que começou a trocar correspondências com Victor Hugo (como dissemos anteriormente) e teve contato com alguns dos autores que mais influenciariam sua trajetória política anos depois - Rousseau e Voltaire. Ela e seu avô discutiam os pensamentos desses autores e, a partir daí, Louise se aproximou das ideias republicanas e as concernentes à educação como meio de levar o homem ao progresso.

Com a morte daquela a quem Louise chamava de avó e, anos depois, a de seu avô, em 1845, ela se viu obrigada a sair do castelo - principalmente por ser acusada pela mulher de Laurent de filha bastarda, logo, sem direito à herança - e buscar um curso normal para formar-se professora. É evidente que não foram somente as necessidades econômicas que a levaram a isso, mas sim sua crença de que a educação poderia levar à evolução do homem.

O sacrifício está realizado. Ontem deixei o velho castelo de Vroncourt, talvez para não mais revê-lo e neste momento estou afastada de minha mãe e em um pensionato, e me proponho a prestar, no mês de agosto, um exame para ser admitida na instrução. (Michel, 2005, p. 45)

Ela ingressou no curso normal para formação de professoras primárias na cidade de Chaumont, formando-se em 1853 e, para continuar próxima de sua mãe, aceitou um cargo em Haute-Marne. Nessa época já eram evidentes as suas convicções republicanas. Para ela, o golpe de Estado e instauração do Império, apoiado pela Igreja, constituíam um entrave ao progresso humano e, por isso, deveria ser derrubado. Em suas aulas, era muito comum que ensinasse seus alunos a cantar a Marselhesa e afirmar que rezar por Napoleão era um sacrilégio. Atitudes como essa a levariam a prestar esclarecimentos diversas vezes.

Louise se manteve em Haute-Marne por alguns anos até conseguir um cargo de professora adjunta em um instituto para meninas e uma sociedade como diretora em um internato, ambos em Paris; era o ano de 1865. Instalou-se no bairro de Montmartre, observado por ela como um local onde podia exercer o ofício de professora, no sentido mais amplo da 
palavra, como passível de levar às mudanças sociais, segundo ela, necessárias ao progresso humano.

Parece-me que o ensino sai um pouco de suas trevas. Será porque encontrei, aqui em Montmartre de que se fala tão mal, um diamante escondido na pessoa da diretora da pensão, minha vizinha, isto é, que realmente haja tendência a compreender melhor o ofício da professora primária, creio que se realiza um progresso. Mas como é lento! (MichEL, 2005, p. 54)

Durante o Império de Napoleão III, Paris crescia e passava por inúmeras reformas. A atividade industrial intensificava-se e, concomitantemente, a cidade atravessava um processo de urbanização acelerada que implicou no surgimento de inúmeros espaços de convivência cultural e lazer. Haussman projetara reformas que transformaram ruas até então estreitas em largos bulevares (estes permitiriam a melhor movimentação das tropas em caso de mobilizações sociais, como as de 1848); também se construíam monumentos, praças, a Ópera Nova, o Chatelet, igrejas e quartéis. Nessa "nova cidade" onde as diferenças sociais eram cada vez mais nítidas, Louise Michel vivia uma vida simples e carregada de preocupações financeiras devido à baixa remuneração paga aos professores.

O pão está caro, o dinheiro é raro Haussman faz subir as rendas,

O governo mostra-se avarento, só os denunciantes tem boa mesada!

Cansado de tão longo jejum que pesa sobre o povinho já é tempo, sim senhor, dele tomar o freio nos dentes!

Dancemos a Bonaparte! Não é a nós que nos presenteamos,

Dancemos a Bonaparte!

Ainda havemos de meter na carta o chilindró! (Michel, 1971, p. 15)

Essas dificuldades e as disparidades sociais cada vez mais evidentes levaram Louise a reafirmar a ideia de que o Império era incapaz de dar conta das transformações políticas, sociais e econômicas pelas quais passava a França da época, longe de ser uma forma de governo em acordo com os 
anseios da população comum. O governo imperial visava somente manter os privilégios de uns poucos indivíduos que o compunham e seria um entrave ao progresso e às "evoluções lentas" (MicheL, 1971, p. 14 e 15) para as quais rumava a humanidade; como acreditava Louise, essa forma governamental, na verdade, significava um retrocesso. Foi justamente por essa crença e por ser adepta dos ideais da República, que ela se aproximou dos grupos republicanos e passou a contestar o aumento abusivo de impostos, a miséria e a guerra franco-prussiana deflagrada pelo governo francês em 1870. O fim do Império, segundo ela, era inevitável e até determinável, mas a população deveria se unir e lutar pela instauração da República, a forma de governo mais popular e que estaria em acordo com as mudanças e com o progresso humano. Foi durante reuniões, nesses grupos republicanos, que Louise conheceu os chefes do Partido Republicano Francês, como Jules Favre, Eugene Pelletan e Jules Simon e, a partir das quais, ela iniciou sua participação ativa, juntamente com aqueles que compartilhavam do ideal republicano, dos eventos que levariam à derrubada do governo imperial.

Vale lembrar que, nesse contexto, não eram somente os republicanos que se colocavam em posição oposta ao Império de Napoleão III; blanquistas, socialistas e anarquistas membros da Associação Internacional dos Trabalhadores (principalmente proudhonianos e bakuninistas) também recriminavam o governo, principalmente depois de declarada a guerra franco-prussiana em 1870. A atuação do exército francês na guerra passou a ser muito criticada pela população; Louise afirmava que as tropas estavam sem suprimentos e com armas, munições e até uniformes em número insuficientes. Juntas, apesar das enormes diferenças político-ideológicas, essas tendências lutaram pela instauração de uma Comuna auto-organizada.

Paris, o maior centro urbano do país - após as intensas transformações sofridas em anos anteriores (como mostramos anteriormente) -, concentrava os protestos e as censuras à guerra, que só aumentavam à medida que os prussianos avançavam e a derrota era cada vez mais premente. Era um terreno fértil para inúmeras mobilizações daqueles que se opunham ao governo. Clamores e reuniões se multiplicavam na cidade em atos como o funeral de Victor Noir, assassinado pelo primo de Napoleão, que acabou por transformar-se em uma grande manifestação pública pela queda do regime, e uma tentativa de blanquistas e outros grupos de tomarem o quartel dos bombeiros do boulevard de La Villette. De forma incontestável, a repressão aumentava quase que na mesma medida dos protestos públicos. Inúmeros manifestantes foram presos e a violência do governo imperial contra a população que tomava as ruas se dava de maneira indiscriminada, como 
Louise relata em suas memórias. Aliás, ela esteve presente nesses atos, já como membro republicano da Internacional dos Trabalhadores, e entregou um abaixo-assinado em nome do povo de Paris para o General Trochu, na tentativa de que seus companheiros Eudes e Brideau fossem soltos, o que evidentemente não ocorreu. A cidade de Paris também foi terreno para inúmeras mudanças no pensamento político de Louise, mas principalmente para suas atuações como militante republicana e anarquista nos dias de Comuna. Ela escrevia (já na época dos primeiros protestos públicos contra o Império de Napoleão III) que era melhor morrer na luta contra o Império do que esperar vivo e continuar na escravidão. Conclamava a população a lutar.

Àqueles que querem continuar a ser escravos: já que o povo quer que a águia imperial continue a planar sobre a sua abjecção. Já que ele continua a dormir, esmagado pelas frias ruínas da eterna opressão;

Já que todos eles, os que são delegados estendem o pescoço submisso ao carrasco, o melhor, amigos, é largar o cutelo e acabar de uma vez com o cobarde rebanho! Um só vale mil quando dá a vida, e diz adeus a todos de uma vez para sempre um por um, iremos, com uma audácia terrível,

porque temos conosco o ferro e o fogo! Basta de cobardes, os cobardes são traidores;

a multidão vil, come, bebe e dorme: se quiseres ficar, fica a lamber os senhores.

Não te chegam já os mortos que tens? $\mathrm{O}$ sangue dos teus filhos faz vermelho o chão dorme sobre os ossos junto aos muros surdos.

Dorme, enquanto, abelha por abelha, cresce o heroico enxame das gentes populares!

Montmartre, Belleville, ó legiões valentes.

Vinde, vinde todas, a hora já chegou. De pé! A vergonha pesa e pesam as cadeias,

De pé! Como é belo morrer! (Michel, 1971, p. 17 e 18)

Apesar da forte repressão, o povo parisiense continuava mobilizado. A situação se complicou definitivamente com a derrota das tropas em Sedan e a prisão do próprio Imperador, em 2 de setembro de 1870. A população - 
avessa à possibilidade de um armistício e afirmando que a Pátria tinha que ser defendida da invasão estrangeira - tomou as ruas junto com os soldados da Guarda Municipal, afirmando que o povo, ao contrário do governo, jamais se renderia. A Câmara Municipal foi invadida, os presos do Império foram postos em liberdade, e a República proclamada (em 4 de setembro de 1870) aos gritos de "Viva a República!". Foi então que Louise passou a fazer parte das frentes armadas. Ela mesma asseverou que a partir daquele momento andaria sempre com a antiga baioneta que ganhara de seus amigos. "Uma vez reconquistada a paz, não se tratava para nós de criar uma república guerreira e agressiva para os outros, mas de instituir a Internacional pelo mundo inteiro sob o ardente impulso das ideias sociais" (Michel, 1971, p. 78).

À proclamação se seguiu a constituição de um governo de Defesa Nacional que tinha, sobretudo, um caráter patriótico: defender a França do inimigo estrangeiro. Salvar a República e os ideais era, antes de tudo, defender a França da invasão dos prussianos, ou seja, defender a Pátria da invasão estrangeira que, a essa altura, era uma ameaça real a Paris. Foram também formados inúmeros comitês de vigilância e clubes, dos quais Louise fazia parte. Aliás, ela presidiu o Clube de Justiça e Paz e o Comitê de Vigilância, ambos de Montmartre, bairro onde morava e lecionava, como já o dissemos. "Amigos, temos a República. O passado sombrio vai acabar. De pé, todos, a hora é heróica. Forte é aquele que sabe morrer" (Michel, 1971, p. 78).

No entanto, não demorou a surgir o descontentamento dela e de grande parte da população parisiense com relação ao novo governo. $\mathrm{O}$ Governo de Defesa Nacional, que unificaria todas as províncias em nome da defesa da pátria da invasão prussiana, liderado por Thiers, passou cada vez mais a deixar seus objetivos de lado (segundo ela) e o armistício era algo cada vez mais próximo e evidente. Além disso, Louise considerava a República como um governo popular, e isso também não se concretizou; a miséria aumentava, assim como os altos preços dos gêneros alimentícios.

Esse momento marcou uma virada de fundamental importância no pensamento e na trajetória política de Louise Michel: ela passou a questionar a própria ideia de governo e poder, ou seja, para ela, qualquer que fosse o governo - Império ou República - sempre assumiria um caráter de traição ao povo, de exploração e manutenção de privilégios de uma minoria, da classe dominante. O governo republicano, para ela, havia negociado às "costas do povo".

Nada havia mudado, uma vez que as engrenagens só haviam mudado de nome; tinham uma máscara nova e nada mais. [...] O que havia afinal era 
uma série de bandidos que combatiam o Império: tinham entrado como esquilos na cabana onde antes deles corriam outros, movendo a mesma roda que outros tinham movido antes deles, e que outros irão mover. Essa roda é o poder esmagando eternamente os deserdados. (MICHEL, 1971, p. 81-89; grifos nossos)

Toda e qualquer forma de governo seria instrumento de dominação, autoridade imposta, ou não, através da força, e seria responsável pela perpetuação do sistema de classes. Os poderes político e econômico corromperiam qualquer indivíduo ou grupo, portanto, eles deveriam ser destruídos e, em seu lugar, deveria ser construída uma sociedade baseada na igualdade, em que os meios de produção, terras e produtos fossem de uso comum, na autogestão e na livre união.

Nesse sentido, as guerras e os acordos (como o do armistício, proposto pelos republicanos) seriam sempre necessários para os governos se manterem - as guerras mantinham o apoio da população ao poder e colocavam um governo em uma melhor "posição" com relação a outros governos. Através dessa conviç̧ão e da descrença no ideal republicano, ela se aproximou cada vez mais dos ideais anarquistas até defendê-los de maneira absoluta, dos dias da Comuna de Paris até o fim de sua vida. Sua crítica ao poder político e [econômico] passou a ser incisiva a partir daí. (Mendes, 2010, p. 131- 132)

Foi exatamente nessa época que Louise se colocou ao lado dos anarquistas, principalmente coletivistas e comunistas, na Associação Internacional dos Trabalhadores. É importante destacar que os anarquistas criticavam o poder político e o econômico que, para eles, estavam intimamente ligados. Em linhas gerais, afirmavam, a burguesia, detentora dos meios de produção, explorava o trabalho da classe proletária através do poder econômico, já que o operário era obrigado a trabalhar ou morrer de fome. E esse poder de explorar, ao qual muitos libertários chamam de escravizar - já que não havia possibilidade de livre escolha e submetia inúmeros indivíduos às péssimas condições de vida que lhes eram impostas -, estava relacionado ao poder político, considerando ser a própria burguesia que o compunha, que se organizava como governo, não a classe trabalhadora. Justamente por isso, o governo era responsável, posto que sua função fosse manter os privilégios de uma classe em detrimento da outra, perpetuando a exploração e a dominação. O poder do Estado (político) estava, então, intrinsecamente ligado ao poder da burguesia (econômico), e um servia de legitimação ao 
outro. Portanto, para os libertários como Bakunin, Malatesta e Louise Michel, a humanidade só seria liberta quando destruísse completamente o Estado e as classes sociais, os poderes político e econômico, e organizasse uma sociedade aberta, composta por unidades ou comunas livremente organizadas e unidas, formando uma grande federação livre.

Houve no mundo, por volta de 71, grandes revoluções ideológicas. Quer em 70, quer antes, quer depois, sempre até que se realize a transformação do mundo, continuará a procura do ideal verdadeiro. Poder-se-á impedir a Primavera de chegar, mesmo que se destruam todas as florestas do mundo? (MicheL, 1971, p. 130)

A desilusão dela era compartilhada por grande parte da população de Paris. As sucessivas derrotas na guerra, a proximidade cada vez maior dos prussianos da capital francesa, assim como as mentiras professadas pelo governo que ocultava as derrotas (transformando-as em vitórias) e apresentava-se como se tudo estivesse "correndo bem" na França causavam grandes críticas e revolta no povo. Havia muitos questionamentos se o governo de Defesa Nacional realmente tinha como intuito defender a pátria. A partir de tais críticas, parte da população parisiense afirmava ser necessário depor imediatamente o governo e instaurar a Comuna que garantiria a proteção da cidade.

Convencida de que o governo republicano estava traindo o povo francês, Louise Michel e outros internacionalistas - de tendências coletivistas, comunistas, proudhoniana e marxistas -, blanquistas e republicanos considerados radicais, passaram a se organizar para continuar defendendo a pátria do inimigo estrangeiro, negando o armistício e formando, assim, uma forte oposição ao governo instaurado em 4 de setembro de 1870 . (Mendes, 2011, p. 40)

Nos diversos clubes formados na cidade, desde os momentos anteriores à proclamação da República, planejavam-se reuniões nas quais se propunham inúmeras manifestações públicas, objetivando derrubar o governo; organizavam-se comitês de vigilância, ambulâncias para socorro de feridos na luta contra os prussianos e, ainda, forças de enfrentamento direto. A Guarda Municipal, que já havia lutado contra o Império, agora também se colocava contra o governo republicano, afirmando que estava ao lado do povo de Paris, contra o armistício, considerado uma traição. Vale colocar que ela era formada por membros saídos dos arrondissements (subdistritos) e 
eleitos pelo corpo eleitoral do bairro em que estivesse sediado cada batalhão. Tais reuniões eram, para Louise, espaços acessíveis, onde se podia exercer a livre iniciativa e a livre união, o que significava preparação moral e material para a revolução social, como afirmavam ela e outros libertários.

Chegavam [para as reuniões livres] todos entre as cinco e seis horas da tarde; resumia-se o trabalho efetuado durante o dia e aquele que havia a fazer para o dia seguinte; conversava-se até o último minuto e, às oito horas, cada qual partia para o seu clube respectivo. (Michel, 1971, p. 99)

Nesses clubes, era grande a presença de mulheres. Aliás, elas estavam presentes em grande número nas diversas e significativas manifestações contrárias às medidas do governo (organizadas por tais clubes nos meses que antecederam a votação da Comuna de Paris) e atuaram ativamente durante os dois meses de sua existência. Em uma dessas manifestações anteriores à proclamação da Comuna, a população parisiense

[...] de variadas tendências político-ideológicas, foi até a Câmara Municipal e entregou ao general Trochu e aos ministros Jules Favre e Jules Simon um documento que exigia a demissão do governo e a instauração da Comuna. O que evidentemente não ocorreu. As reuniões livres nos clubes, no entanto, não pararam, apesar das perseguições do governo, do fechamento de clubes e jornais e impedimentos de reuniões. Organizava-se uma força armada para decretar a Comuna na cidade de Paris. Os jornais fechados pelo governo foram substituídos por cartazes que informavam sobre movimentações e reuniões. Aliás, durante os meses que se seguem, em que a Comuna existiu e resistiu, a população parisiense se comunicava, organizava ações e a própria vida cotidiana da cidade, através desses cartazes. Os acontecimentos também eram quase que imediatamente divulgados através deles. (Mendes, 2011, p. 41)

Apesar dessa intensa atividade desde setembro de 1870, um fato é destacado por Louise (agora, libertária convicta) como essencial para a definitiva ruptura da população francesa com o governo republicano instalado em Versalhes: em 22 de janeiro de 1871, uma grande multidão dirigiu-se à Câmara Municipal de Paris para protestar, mas o governo autorizou o exército a abrir fogo contra ela e inúmeros manifestantes foram mortos e feridos. A partir daí tornou-se clara a distância entre o povo e o governo de Defesa Nacional; Versalhes e Paris se colocaram em posições opostas. As ruas foram tomadas por comícios e agitações, nos quais Louise lutava ativamente. "O governo, jurando sempre que jamais se entregaria, 
tentou silenciar as reuniões particulares, as câmaras federais, os clubes; então tudo se tornou clube, a rua fez-se tribuna, as próprias calçadas se amotinavam" (Michel, 1971, p. 112).

Ela narrou a manifestação de 22 de janeiro, afirmando seu horror diante da fuzilaria, da "chuva de balas" e da violência do governo sobre o povo, que concentrado na praça em frente à Câmara Municipal protestava (principalmente pelo racionamento de pão), e outras pessoas inofensivas que estavam ali, por acaso, e que foram assassinadas.

Outra reunião dos grupos que exigiam a demissão do governo, ocorrida em fevereiro de 1871, resultou uma decisão essencial à organização prática da Comuna: formar-se-ia um Comitê Central, livremente eleito. Ele seria composto por três delegados de cada arrondissement (subdistrito) da cidade, sem que houvesse qualquer distinção de grau entre eles. Tal comitê seria parte integrante da Federação da Guarda Nacional, também composta por uma Assembleia Geral dos Delegados, círculos de batalhão e conselhos de legião.

Essa organização era vista por Louise Michel e seus companheiros coletivistas, comunistas e proudhonianos, como organização federal, uma das expressões da organização anarquista que acreditavam ser fundamental para a revolução social e para a organização da sociedade livre. (MENDEs, 2011, p. 41; grifos nossos)

Grosso modo, a organização federal da qual falamos acima (para a maioria dos libertários) era a forma como deveria ser constituída a sociedade anárquica, após a derrubada do Estado, a expropriação da burguesia e a total destruição das classes sociais. Seria instituída livre e espontaneamente por outras inúmeras associações (uniões de produtores ou comunas), também organizadas e norteadas pelo princípio da autogestão, em que os meios de produção, a terra e o trabalho fossem totalmente coletivos ou comuns, sem qualquer governo, autoridade ou hierarquia social.

A luta de Louise Michel por construir a Comuna provinha dessa ideia; abolindo-se o Estado e as classes sociais, transformar-se-iam em coletivos e comuns os meios de produção, terras e instrumentos de trabalho. Assim a organização comunal seria também o próprio cerne da organização social futura, na qual se consagraria a federação de comunas livres. Portanto, era como anarquista, inspirada nas ideias de Proudhon e Bakunin, que Louise via a Comuna: a realização dos ideais libertários na prática e não somente um meio de se assegurar a defesa da pátria. Aliás, o ideal patriótico era 
rejeitado por ela, ao afirmar que a existência de Estados e de fronteiras era contrária à natureza humana de ser sociável. Portanto, a Comuna era a forma de libertação dos trabalhadores pelos próprios trabalhadores, pautados nos princípios de solidariedade e união. Em "Mis recuerdos de la Comuna" (1973), a versão espanhola de suas memórias, Louise publicou um texto, assinado por membros da Internacional, que resumia aquilo que ela pensava sobre a Comuna de Paris.

Somos ateos porque el hombre no será jamás libre mientras no haya expulsado a Dios de su inteligência y de su razón. [...] Que la Comuna libre para siempre la humanidad de este espectro de sus miserias pasadas, de esta causa de sus miserias presentes. En la Comuna, no hay lugar para el sacerdote: toda manifestación, toda organización religiosa debe ser proscrita.

Somos comunistas, porque queremos que la tierra, que las riquezas naturales dejen de ser apropiadas por algunos, y que pertenezcan a la comunidad. Porque queremos que libres de toda opresión, dueños al fin de todos los instrumentos de producción: tierra, fábricas etc., los trabajadores conviertan el mundo en un lugar de bienestar y ya no de miséria. [...] Al destruir la propiedad individual, el comunismo hace caer una a una todas esas instituiciones de las que la propiedad es el eje [...] Con el aniquilamento de las clases, desaparecerán todas las instituciones opresivas del individuo y del grupo, cuya única razón de ser era el mantenimiento de esas clases, la sujeción del trabajador a sus amos. [...] Somos revolucionarios, o comuneros, porque, queriendo la victoria, queremos sus medios; porque comprendiendo las condiciones de la lucha, y queriendo cumprirlas, queremos la organización más fuerte de combate, la colición de los esfuerzos, no su dispersión, sino su centralización. [...] La Comuna es la forma militante de la Revolución Social.

El grupo: La Comuna Revolucionaria. Aberlen, Berton, Breuillé, Carné, Jean Clément, F. Counet, Ch. Dacosta, Delles, A. Derouilla, É Eudes, H. Gausseron, E. Góis, A. Goullé, E. Granger, A. Granger, A. Huguenot, E. Jouanin, Ledrux, Léonce Luillier, P. Mallet, Marguerittes, ConstantMartin, A. Moreau, H. Mortier, A. Oldrini, Pichon, A. Poirier, Rysto, B. Sachs, Solignac, Ed. Vaillant, Varlet, Viard. (MicheL, 1973, p. 437-440; grifos nossos)

Foi em 26 de março de 1871, segundo ela, que a população parisiense votou pela Comuna e decretou que não reconhecia mais o governo de Versalhes como legítimo. "A França não foi salva nem militar e nem revolucionariamente, mas degolada pelos burgueses degenerados. $\mathrm{O}$ futuro pertence, portanto, à Revolução libertadora" (Michel, 1971, p. 125). 
Soldados, exército e marinha se colocaram a favor da população e recusaram-se a defender o governo republicano e, em 28 de março do mesmo ano, o povo proclamava a Comuna entre tiros de canhão e gritos de "Viva a Comuna!". Mesmo convicta de que a Comuna deveria ser proclamada revolucionariamente e não através de eleições, Louise, além de colaborar com os comitês de vigilância (dos quais já fazia parte antes da proclamação da Comuna), atuar como enfermeira nas ambulâncias de socorro a feridos e lutar nas barricadas, engajou-se rapidamente no $61^{\circ}$ Batalhão de Marcha de Montmartre. Para ela a luta armada era fundamental à revolução social e era meio essencial de se assegurar a existência da Comuna que representava tal revolução.

A proclamação da Comuna foi qualquer coisa de fantástico e de extraordinário. Não era a festa do poder, mas a pompa do sacrifício: sentia-se que os eleitos estavam prontos para morrer. Na tarde de 28 de março, uma tarde cheia de sol, que lembrava a aurora do 18 de março, ou a do 7 Germinal do ano 79 da República, o povo de Paris que votara na Comuna, entrou triunfalmente no edifício da Câmara. Havia um mar humano debaixo de armas; as baionetas pareciam espigas de um campo; ouviam-se os tambores de Montmartre. (Michel, 1971, p. 167)

Desde os primeiros dias da Comuna, Louise Michel combateu com o $61^{\circ}$ Batalhão nas muralhas, principalmente no forte de Issy, na estação de Clamart e em Neuilly; porém, é interessante notarmos que ela não deixou de acreditar que a educação poderia levar às transformações sociais e de observála como meio de propagar a solidariedade e apoio mútuo, bases capitais da sociedade livre e igualitária. Mesmo atuando em levantes armados - desde os meses que antecederam à proclamação e nas lutas pela defesa da Comuna de Paris -, ela não abandonou totalmente as escolas que havia fundado e nas quais lecionava, onde continuava a propagar ideais libertários. Nos dias de combate ao lado de seus companheiros de Batalhão, amigos e sua mãe tomavam conta da escola.

[...] Eu tinha três cursos: o de literatura, onde era fácil encontrar citações de autores antigos que se adaptassem à situação atual; o de geografia antiga, onde as investigações e os nomes do passado levavam às investigações e aos nomes presentes, e onde se podia imaginar o futuro sobre as ruínas do passado. [...] Tinha ainda [...] um curso de desenho. [...] Quando as coisas se complicaram, Charles Sirvry passou a dar as aulas de literatura e Mademoiselle Potin, minha amiga e camarada, ficou com as aulas de desenho. (Michel, 1971, p. 134; grifos nossos) 
Em seus escritos, Louise Michel deixou evidente sua crença na experiência de 1871. Ela destacava que os primeiros dias de Comuna foram prósperos: as artes e as ciências puderam se desenvolver livremente; os cultos religiosos haviam sido abolidos; assim como se havia estabelecido justiça e certa equidade social ao se confiscar bens de raiz, colocar à disposição das sociedades de trabalho as oficinas abandonas por seus donos, abolir multas em ambientes de trabalho, proibir a acumulação de empregos, fixar salários máximos e mínimos (para professores, por exemplo) e instituir pensão aos familiares daqueles que haviam sido mortos ou feridos na guerra francoprussiana, ou nas lutas pela construção da Comuna. No entanto, apontava que, para se perpetuar a Comuna deveria ter sido expropriada a classe exploradora e confiscado o dinheiro do Banco Nacional, o que não ocorreu. Os discursos políticos profissionais haviam sido abolidos e os presos de Versalhes soltos, porém a propriedade privada não havia sido extinta, como ela reivindicava junto com seus companheiros anarquistas; ainda assim, em momento algum deixou de lutar em defesa da Comuna durante os seus dois meses de existência.

Se algum poder podia fazer qualquer coisa, esse poder era o da Comuna, constituída por homens inteligentes e cheios de coragem, com uma honestidade inacreditável; homens que tinham dado, desde sempre, provas de uma devoção e de uma vontade para o sacrifício; souberam morrer heroicamente. O poder é maldito e é por isso que sou anarquista. (Michel, 1971, p. 168; grifos nossos)

Para Louise, qualquer poder político ou econômico era maldito; legítimo mesmo era o poder do povo que construía, de maneira livre e igualitária, a Comuna. Esta, sim, poderia significar a constituição de uma sociedade totalmente anárquica, em que (como afirmamos anteriormente) os meios de produção, terra e o resultado do trabalho de todos seriam comuns. Ela e seus companheiros de luta libertária defendiam que:

[...] a consolidação de uma Comuna livre através da luta armada seria a possibilidade de construir uma sociedade nova, comunista e igual para todos. Só assim se poderia viver em plena liberdade, igualdade e em solidariedade e apoio mútuo, unindo-se livremente para maior desenvolvimento individual e, consequentemente coletivo (já que para ela o indivíduo desenvolve sua personalidade em contato com a comunidade de indivíduos, que só podem ser verdadeiramente livres e felizes em comunidade), [dentro do princípio da livre união]. (MeNDEs, 2010, p. 135) 
Foi justamente por essa crença e por afirmar a necessidade de se destruir o governo para que a mesma se concretizasse que, juntamente com o $61^{\circ}$ Batalhão, Louise saiu em marcha para atacar Versalhes em 3 de abril e assim permaneceu até maio. Em suas memórias, ela afirmou que pensara em matar Thiers, um dos líderes do governo republicano; só mudou de ideia por acreditar que isso poderia significar um "duro golpe" à Comuna. "[...] nem era o medo de morrer, nem o de matar que dominava o pensamento, mas sim o ideal realizável através da luta armada" (Michel, 1971, p. 190).

A Comuna de Paris de 1871 teve apoio de sindicatos, de maçons em diversas regiões da França e em outros países, no entanto foi dura e violentamente reprimida pelo governo francês. Mortes e prisões aumentavam a cada dia e as munições dos batalhões - como do $61^{\circ}$ Batalhão de Marcha, do qual Louise fazia parte de maneira tão intensa que raramente dormia uma noite inteira e nunca visitava sua mãe - foram reduzidas na luta contra Versalhes, até acabarem completamente. A resistência era quase heroica. Era intenso o trabalho de Louise e de outras mulheres nos batalhões, nas ambulâncias e no socorro às vítimas. Aliás, as mulheres atuaram em grande número na luta e na organização da Comuna.

Eis as mulheres com a sua bandeira vermelha, furada pelas balas, saudando os federados; foram elas que organizaram um serviço de ambulâncias para o forte; daqui [do forte de Issy] os feridos são transportados para Paris. Dispersamo-nos para podermos ser mais úteis. Eu fui para a estação de Clamart, batida durante todas as noites pela artilharia de Versalhes. Subia-se ao forte de Issy por uma pequena colina rodeada de sebes; o caminho estava todo florido e cheio de violetas que abafavam os tiros. Próximo, havia um moinho de pedra; éramos poucos nas trincheiras de Clamart; se o canhão do forte não nos defendesse poderia haver surpresas. Os homens de Versalhes ignoravam sempre nosso reduzido número. (Michel, 1971, p. 194)

No entanto, a Comuna não conseguiu manter-se "em pé" por muito tempo. Louise Michel narrou que em toda a parte havia soldados enviados pelo governo, conspiradores e traidores que observavam e avisavam sobre os pontos fracos na segurança comunal. Diversas mulheres erguiam barricadas na Praça Blanche e na Praça Pigalle; Louise estava com o exército para o combate no cemitério de Montmartre e na barricada da Chaussée Clignancourt. Em seus relatos, ela afirmava que nos meses de luta pela Comuna "raramente vestia-se com saias e vestidos; ao contrário, são comuns 
suas fotos, na iconografia da Comuna, com uniforme militar da Guarda Nacional" (Mendes, 2011, p. 42-43), assim como o são seus relatos sobre o uso de um punhal, de uma espingarda e uma carabina, desde as mobilizações que antecederam à proclamação.

[...] Algumas granadas explodiam a intervalos regulares; dir-se-ia as badaladas de um relógio, o relógio da morte. Naquela noite clara, embriagada pelo perfume das flores, os mármores pareciam-me vivos [Louise e outros federados encontravam-se no cemitério de Montmartre, um dos últimos redutos da resistência]. Andávamos em investigações e a granada regular caía constantemente, as outras variavam. Quis regressar sozinha. Dessa vez, a granada, ao cair perto de mim, através dos ramos, cobriu-me de flores. Foi junto do túmulo de Mürger. A figura branca, lançando sobre um túmulo flores de mármore, produzia um efeito encantador. [...] Ao regressar para junto de meus camaradas, perto do túmulo sobre o qual está deitada a estátua de bronze de Cavaignac, oiçolhes esta recomendação: "Desta vez, não sai mais daqui." Fico ao pé deles. Das janelas de algumas casas partem os tiros. Suponho que chegou o dia. Temos mais feridos por causa das granadas. O grupo reduz-se. Eis o ataque; são preciosos reforços. Enquanto se põe a questão de quem deverá vir, eu já estou longe, tendo-me esgueirado por um buraco do muro. (MicheL, 1971a, p. 60)

Como já dissemos, as mortes aumentavam dia a dia e o governo (com sede em Versalhes), abrindo fogo contra o povo de Paris, entrou definitivamente na capital francesa em 21 de maio de 1871 pelas portas de Saint-Cloud, Anteuil e Passy. Depois de sete dias de resistência, em 28 de maio, a Comuna de Paris estava totalmente liquidada. Seguiram-se ao fim inúmeros fuzilamentos e prisões. "A Comuna estava morta, sepultando com ela milhares de heróis desconhecidos" (Michel, 1971a, p. 75).

Após a queda definitiva da Comuna de Paris, Louise Michel ainda conseguiu fugir e esconder-se; no entanto, como sua mãe fora presa pelo governo de Versalhes, decidiu entregar-se em troca da soltura daquela que sempre a apoiara nos dias de luta. Foi enviada à prisão de Sartory e depois à de Chantier com outras mulheres que haviam participado da Comuna. Durante os primeiros dias na prisão, enquanto aguardava julgamento, Louise Michel, como afirma em suas memórias, pensava que seria fuzilada como muitos de seus companheiros, o que não ocorreu, (segundo ela) porque já não havia mais lugar para tantos mortos na cidade de Paris: "as valas comuns estavam cheias, assim como o rio Sena e as ruas" (Mendes, 2010, p. 137). O cheiro da carnificina estava presente em toda a parte. As filas de prisioneiros 
eram imensas; todos eram levados para as prisões a pé para que a população pudesse observar o que ocorria com aqueles que se opunham ao governo. Na prisão de Chantier, Louise era conhecida como uma das presas com pior comportamento: lançara sobre a cabeça de um oficial que trabalhava na prisão uma garrafa de café (enviada clandestinamente por sua mãe), fazia caricaturas de visitantes e, ainda, reivindicou que as mulheres burguesas não fossem fazer caridade na cadeia para não "emporcalhar a Comuna" (MicheL, 1971a, p. 105). Por esse comportamento foi levada, com outras trinta e nove mulheres, ao correcional de Versalhes.

No correccional, o regime das quarenta piores foi singularmente abrandado: deram-nos autorização para tomarmos banho, forneceramnos roupa branca [até então as mulheres vestiam a roupa do corpo desde que foram presas, não haviam tomado banho e muitas tomaram chuva enquanto permaneciam nas filas de prisioneiros] e permitiram a visita dos familiares. (Michel, 1971a, p. 106)

Depois do correcional, Louise ainda foi transferida para a prisão de Arras, de onde aguardaria o julgamento do Conselho de Guerra de Versalhes. Este terminou por condená-la por luta armada em movimento insurrecional e a pena imposta foi deportação com prisão em fortificação, o que a levou à Nova Caledônia - conjunto de ilhas, próximas da Austrália, então colônia francesa. Ela negou-se a apelar aos juízes sobre essa condenação, afirmando:

Não quero que nada seja mudado em minha condenação e tenho o direito de exigir que ela continue tal como foi pronunciada. [...] Se vos falo de mim é porque sou e continuarei sendo daqueles que carregam tanto mais alto sua bandeira quanto mais ela é despedaçada; enquanto me restar um sopro de vida, ele pertencerá à revolução vencida e acredito que se ela nunca mais se levantar eu despertaria do túmulo. [...] Meu único dever neste momento é continuar digna daqueles que estão mortos e daquilo que queríamos. O futuro nos julgará. (MiCHEL, 2005, p. 68-69; grifos nossos)

Mesmo na Nova Caledônia, Louise Michel continuou a dar aulas para filhos de franceses presos, e mesmo para os nativos, em uma escola montada por ela mesma. Aliás, nesse sentido, ela afirmava que aprendia mais com eles do que lhes ensinava. Aprendeu dialetos locais e os costumes das tribos canacas, estudou diversas espécies de plantas e insetos, e morou com uma tribo, chegando a participar de uma rebelião organizada por uma das tribos nativas. "Aqui não sinto nenhum tédio e vejo sem emoção algumas partidas; 
parece que me tornei de mármore, [...] mais vale morrer do que retornar antes de uma anistia geral (Michel, 2005, p. 82).

Essa anistia, a qual Louise nem aguardava com ansiedade, ocorreu em 1880. Do barco que a levava para Londres, ela afirmou não querer voltar e que sentiria saudades do que encontrou na Nova Caledônia, porém considerava que seria mais útil na Europa, onde poderia difundir os ideais anárquicos para mais pessoas e com maior intensidade. De Londres, onde fixou residência, viajou por toda a Europa dando conferências em que propagava as ideias libertárias e defendia a ação direta; era considerada excelente oradora e ovacionada por aqueles que a ouviam. Participou de movimentações operárias, greves e escreveu peças teatrais e poesias, que seguiam os propósitos da arte engajada e comprometida com a revolução social defendida pelos anarquistas.

[...] no amó el arte por el arte. Ningún poeta proclamó con mayor fuerza que el artista tiene una misión social que cumplir y que la obra de arte debe constituir una acción. La obra maestra hacia cuya consecución deben tender finalmente todas las fuerzas del artista es su propia vida. (BOYER, 1946, p. 10; grifos nossos)

Essa intensa atividade anárquica a levou à prisão por outras diversas vezes. Além disso, chegou a sofrer um atentado enquanto dava uma conferência aos trabalhadores franceses; porém Louise Michel, no julgamento, defendeu o homem - Pierre Lucas - que atirara nela, afirmando que ele estava desesperado por causa do desemprego e do uso do álcool.

Lutou e propagou os ideiais libertários até o dia de sua morte, em 10 de janeiro de 1905. Seu corpo foi levado a Paris, para o cemitério de LevalloisPerret, onde estava enterrada a sua mãe, sua amiga Maria Ferré e Théophile Ferré, único homem pelo qual se apaixonou e que viu ser fuzilado em 1871, logo após o fim da Comuna.

Louise Michel afirmava que "homens e mulheres não estavam em posições opostas. As opressões, sentidas por um e por outro, embora diferentes, eram fruto da mesma fonte: da sociedade capitalista de classes" (Mendes, 2010, p. 137) e suas instituições políticas, econômicas, sociais; enfim [...] "juntos, homens e mulheres deveriam lutar para derrubá-la e alcançar a libertação total, através da construção, em igualdade, da sociedade anarquista e comunista, pautadas nos princípios de solidariedade e união" (Mendes, 2010, p. 137-138). Para Louise, a Comuna seria o próprio cerne dessa sociedade. Na sociedade capitalista, ela funcionaria como uma organização livre na qual se aprenderia a solidariedade e o apoio mútuo na 
prática; se levasse à expropriação total da burguesia, poderia ser um meio de revolução social. Já na sociedade anárquica, seria a base organizacional dessa "nova sociedade".

Para ela a Comuna de Paris de 1871 não teve seu fim decretado com a entrada dos versalheses na cidade; seu legado estaria em suas ideias, na conquista que ela significou ao unir - apesar de todas as diferenças de pensamento e ação - membros de diversas correntes políticas e ideológicas. As ideias presentes nos dois meses de existência da Comuna perdurariam pela eternidade. “[...] Não podemos matar as ideias a tiros de canhão nem tampouco algemá-las. O fim apressa-se tanto mais quanto o verdadeiro ideal surge, belo e poderoso, superior a todas as ficções que o precederam" (Michel, 1971, p. 8).

\section{Louise Michel and the Paris Commune}

Aвstract: The current article aims essentially to understand the Paris Commune of 1871 as the historical experience of struggle that has fundamental importance for the labour movements of subsequent periods of History around the world. We did it through the perspective of its historical subjects, seeking to recover memories, trajectories and present ideas in the reports of Louise Michel, one of the most active characters of the Commune. Louise began her struggle as a republican, since the Franco-Prussian War - where are the roots of her experience of fighting as a convinced anarchist - until its last days in May 1871, when the communards were killed or captured after relentless siege of the Versailles government to Paris. Louise Michel, however, did not stop her struggle for liberation with the final end of the Paris Commune of 1871; she continued fighting in exile in New Caledonia, and throughout Europe after the amnesty of 1880. This fight was also addressed in this article.

KEY wORDs: Louise Michel, Social History, Paris Commune, the anarchist movement.

\section{REFERÊNCIAS}

Boyer, I. Luisa Michel - la virgen roja. Tradução de Antonio R. Costa. Buenos Aires: Editorial Futuro, SRL, 1946.

Mendes, S. C. As mulheres anarquistas na cidade de São Paulo (1889-1930). Franca, 2010. Dissertação (Mestrado - PPG História) Unesp.

Mendes, S. C. A Comuna de Paris segundo Louise Michel. Revista Espaço Acadêmico, Maringá, UEM, ano X, n. 118, mar. 2011.

Michel, L. A Comuna 1. Tradução de Armando da Silva Carvalho. Lisboa: Editorial Presença, 1971. 
Michel, L. A Comuna 2. Tradução de Maria Clarinda Brás e Armando da Silva Carvalho. Lisboa: Editorial Presença, 1971a.

Michel, L. Mis recuerdos de la Comuna. México: Siglo Veintiuno, 1973.

Michel, L. Cartas a Victor Hugo. Tradução de Ana Paula Castellani. Vinhedo, SP: Ed. Horizonte, 2005. 